\title{
The use of fluorescein diacetate to assess embryo viability in the mouse
}

\author{
Linda R. Mohr and A. O. Trounson \\ Department of Obstetrics and Gynaecology, Monash University, Queen Victoria Medical \\ Centre, 172 Lonsdale Street, Melbourne, Australia 3000
}

\begin{abstract}
Summary. Preimplantation mouse embryos that were exposed to fluorescein diacetate (FDA) accumulated intracellular fluorescein and fluoresced brightly under ultraviolet (u.v.) light. The rate at which intracellular fluorescein was lost from the cells was measured at 37,28 and $4^{\circ} \mathrm{C}$ and the rate decreased as the storage temperature decreased. The rate at which intracellular fluorescein accumulated increased as FDA concentration increased until a maximum rate was attained. The ability to accumulate intracellular fluorescein could be removed by heating embryos at $56^{\circ} \mathrm{C}$ for $30 \mathrm{~min}$ or by damaging the cell membrane. Cells grown under inadequate culture conditions lost the ability to accumulate intracellular fluorescein. Exposure of 2-cell mouse embryos to FDA and u.v. light did not alter the rate of blastocyst formation in vitro, and exposure of blastocysts to FDA and u.v. light did not alter the rate of implantation or post-implantation development in vivo.
\end{abstract}

\section{Introduction}

The viability of mammalian preimplantation embryos is generally assessed on the basis of their morphological appearance, their ability to continue development in vitro or to produce live young when transferred to foster mothers (see Whittingham, 1978, for review). Assays of viability by assessing metabolic activity have been used for rabbit embryos (Anderson \& Foote, 1974,1975 ) but these tests involved lengthy incubations with radioactive precursors and destruction of the embryos. No rapid, non-toxic assay of biochemical activity is currently used to assess the viability of preimplantation embryos.

Rotman \& Papermaster (1966) reported the use of fluorescein diacetate (FDA) to assess the viability of cell lines cultured in vitro because living mammalian cells accumulate intracellular fluorescein when exposed to FDA ('fluorochromasia'). The model proposed by Rotman \& Papermaster (1966) to explain fluorochromasia is that FDA, being non-polar, can readily pass into the cell where it is hydrolysed by esterases to yield fluorescein. The polar fluorescein cannot readily cross the cell membrane and therefore accumulates intracellularly. The test is a measure of both esterase enzyme activity and membrane integrity. The incubation times required in this test are short, 1 min (Rotman \& Papermaster, 1966), 8 min (McGrath, Cravalho \& Huggins, 1975 ) and 10 min (Persidsky \& Baillie, 1977). Rotman \& Papermaster (1966) demonstrated that viability and fluorochromasia are closely linked by a one-to-one correspondence between fluorescence and cloning ability and that exposure to FDA did not alter subsequent cloning ability. McGrath et al. (1975) have shown that when cells are exposed to FDA before freezing, loss of fluorescence after freezing and thawing is related to intracellular ice formation and subsequent membrane damage. Leibo \& Mazur (1978) have reported the use of FDA to assay survival of mouse embryos after freezing and thawing. There is a high correlation ( 0.96$)$ between the ability of embryos to fluoresce and their ability to develop in culture after freezing and thawing (Jackowski, 1977). 
The present study was undertaken to define the conditions required for optimum sensitivity of the fluorescein diacetate test for preimplantation embryos and to determine the value of the test for assessing embryo viability under various conditions in vivo and in vitro.

\section{Materials and Methods}

Source of embryos

Random-bred Swiss albino mice, 6-8 weeks old, were induced to superovulate with 10 i.u. PMSG (Folligon: Intervet Ltd) followed $48 \mathrm{~h}$ later by 10 i.u. hCG (Chorulon: Intervet Ltd). Fertilized 1-cell, 2-cell, morula and blastocyst stage embryos were collected by flushing the reproductive tract on Days 1, 2, 3 or 4, respectively, when Day 1 is the day of finding a vaginal plug. Embryos were flushed out in modified Dulbecco's phosphate-buffered saline (PB 1; Whittingham, 1971), which contains $4 \mathrm{mg} \mathrm{BSA} / \mathrm{ml}$.

\section{Culture}

Embryos were cultured in modified Whitten's medium (Hoppe \& Pitts, 1973) in tissue culture tubes (Falcon; $12 \times 75 \mathrm{~mm}$ ). The culture medium was placed in the tubes in an atmosphere of $5 \% \mathrm{CO}_{2}$ in air at $37^{\circ} \mathrm{C}$ for a minimum of $12 \mathrm{~h}$ before embryo culture. The embryos were transferred to the tubes of medium in a small volume of PB 1 immediately after collection and cultured in unsealed tubes in $5 \% \mathrm{CO}_{2}$ in air at $37^{\circ} \mathrm{C}$.

\section{FDA viability test}

A stock solution of $5 \mathrm{mg}$ FDA (Sigma) $/ \mathrm{ml}$ acetone was prepared and stored at $-20^{\circ} \mathrm{C}$. Just before use a solution of $0.5 \mu \mathrm{lstock} / \mathrm{ml}$ PB 1 was prepared giving a final concentration of $2.5 \mu \mathrm{g}$ $\mathrm{FDA} / \mathrm{ml}$. Embryos were incubated in this solution for $1 \mathrm{~min}$ at room temperature $\left(24-28^{\circ} \mathrm{C}\right)$. Embryos were transferred to PB1 solution at room temperature and washed for a minimum of 1 $\min$.

\section{Optics}

Whole mount preparations of the embryos were examined at a magnification of $\times 256$ with a Zeiss photomicroscope III set on phase-contrast optics. All observations under ultraviolet (u.v.) light were carried out using a Zeiss combination of filters (Zeiss 487709) which contained an excitor filter $P_{B} 450-490$, chromatic beam splitter FT5 10 and barrier filter LP520. Fluorescence was measured semi-quantitatively using a centre-field light sample. In principle a small sample of light from the field is fed into a photomultiplier and when a set amount of light is received the camera mechanism is triggered. The time taken to trigger the camera was recorded using a stopwatch when the sample of light was taken from the centre of an embryo exposed to u.v. light only. The centre-field sample was approximately one-ninth the area of a 1-cell embryo, and was placed in the centre of a 1-cell embryo or morula and in the centre of one blastomere of a 2-cell embryo. The time taken to trigger the camera for different amounts of fluorescence ranged from less than $1 \mathrm{sec}$ to $30 \mathrm{sec}$ on ASA 800. For very short exposure times the ASA setting was lowered until the time to trigger the camera was a minimum of $2-3 \mathrm{sec}$. The times to trigger when different ASA settings were used were converted to the time at 800 ASA. ASA setting and exposure time were linearly related over these times. The linearity of the photomultiplier over these exposure times was checked and found to contribute an error of less than $2.5 \%$ at exposure times up to $30 \mathrm{sec}$. All photographs were recorded on Ilford HP5 (400 ASA) film 
exposed at $800 \mathrm{ASA}$ and triggered by light from a centre field sample. The magnification $(\times 156)$ was constant for all fluorescent recording.

\section{Transfer of embryos}

Embryos to be transferred were collected at the blastocyst stage of development. All embryos collected each day were pooled and half were exposed to FDA as described above. FDA-treated embryos were placed on a sterile depression slide exposed to u.v. light for 10 sec. Control embryos were meanwhile stored in PB1 in the incubator. Embryos were transferred to the uterine horns of Day-3 pseudopregnant recipients obtained by caging females with vasectomized males as described by Whitten \& Champlin (1978). Recipients were killed 14 days after the transfer of embryos and the fetuses were examined.

\section{Results}

Fluorescence was graded in the following manner: Grade 5, very bright and uniform fluorescence within celis, $<1 \mathrm{sec}$ to trigger the camera; Grade 4, bright and uniform fluorescence, 1-3 sec to trigger the camera; Grade 3, uniform fluorescence, 3-7 sec to trigger the camera; Grade 2, pale and uniform or patchy fluorescence within cells, 7-20 sec trigger time; Grade 1, pale, often patchy, fluorescence within cells, just detectable visually, 20-30 sec trigger time; Grade 0, no fluorescence visible, $>30 \mathrm{sec}$ trigger time.

\section{Freshly collected embryos}

All preimplantation embryos, at the appropriate stage of development when flushed from the reproductive tract, accumulated sufficient intracellular fluorescein after exposure to FDA for 1 min to fluoresce brightly under u.v. light. Embryos retarded in development did not accumulate as much intracellular fluorescein when exposed to FDA as did the morphologically normal embryos (Table 1). Fluorescence was always within the cell membranes and never appeared within the zona pellucida or perivitelline space (Pl. 1, Figs 1 and 2).

Table 1. The fluorescent light intensity of freshly collected mouse embryos after 1 min exposure to FDA

\begin{tabular}{|c|c|c|c|c|}
\hline \multirow{2}{*}{$\begin{array}{c}\text { Day of flushing* } \\
\text { (Day } 1 \text { is day of ovulation) }\end{array}$} & \multirow[b]{2}{*}{ Stage of embryo } & \multirow{2}{*}{$\begin{array}{l}\text { No. of } \\
\text { embryos }\end{array}$} & \multicolumn{2}{|c|}{ Grade of fluorescence } \\
\hline & & & Mean & Range \\
\hline 1 & 1-cell & 38 & $4 \cdot 2$ & $4-5$ \\
\hline \multirow[t]{2}{*}{2} & 2 -cell & 21 & $4 \cdot 3$ & $4-5$ \\
\hline & 1-cell & 2 & 4.0 & - \\
\hline \multirow[t]{2}{*}{3} & Morula & 19 & $4 \cdot 5$ & $4-5$ \\
\hline & 1-cellt & 10 & 0.8 & $0-2$ \\
\hline \multirow[t]{3}{*}{4} & Blastocyst & 19 & $4 \cdot 4$ & $4-5$ \\
\hline & Morula & 6 & 3.8 & $2-5$ \\
\hline & 1-cell† & 8 & 0.4 & $0-2$ \\
\hline
\end{tabular}

* Day 1 is day of ovulation.

† Includes fragmenting and degenerate 1-cell embryos.

A 1-min wash in PB1 at room temperature was sufficient to remove all non-hydrolysed FDA from within the cells. Freshly collected morulae or 1-cell embryos heated at $56^{\circ} \mathrm{C}$ for $30 \mathrm{~min}$ and exposed to FDA no longer accumulated intracellular fluorescein. A 1-min wash in PB 1 removed all non-hydrolysed FDA from heat-inactivated embryos and these embryos fiuoresced at Grades 
$0-1$. The inability to accumulate intracellular fluorescein displayed by heated embryos was not caused by a change in membrane permeability to fluorescein: heat-treated embryos and untreated embryos were able to exclude fluorescein when exposed to a solution of fluorescein in PB1 (PI. 1, Figs 3, 4, 5 and 6).

\section{Membrane integrity}

Membrane damage was associated with a complete loss of fluorescence. Mouse embryos with membrane damage, of unknown origin, occurring in vivo accumulated no intracellular fluorescein (Pl. 1, Figs 7 and 8). When 1-cell mouse embryos which had accumulated intracellular fluorescein were damaged by piercing the membrane, all accumulated fluorescein was lost (Pl. 2, Figs 9 and 10).

\section{Loss and accumulation of intracellular fluorescein}

The rate at which intracellular fluorescein was lost from 1-cell embryos was dependent on the temperature at which they were stored. At $37^{\circ} \mathrm{C}, 50 \%$ of the initial intracellular fluorescein was lost in $30 \mathrm{~min}$ and less than $5 \%$ remained after $2 \mathrm{~h}$. At room temperature $\left(28^{\circ} \mathrm{C}\right), 50 \%$ was lost after $1 \mathrm{~h}$ while at $4^{\circ} \mathrm{C}$ less than $5 \%$ was lost in the first $2 \mathrm{~h}$ (Text-fig. 1).

\section{PLATE 1}

Figs 1 and 2. A phase-contrast (Fig. 1) with corresponding u.v. light (Fig. 2) photograph of freshly collected 1-cell, 2-cell, morula and blastocyst stage mouse preimplantation embryos exposed for $1 \mathrm{~min}$ to FDA and washed $1 \mathrm{~min}$ in PB 1. Partly shown is a degenerating 1-cell embryo found $72 \mathrm{~h}$ after ovulation. Note the localization of fluorescence within the cell membranes.

Figs 3 and 4. Five freshly collected 1-cell mouse embryos exposed to FDA and photographed as for Figs 1 and 2. Two of the embryos had been heated at $56^{\circ} \mathrm{C}$ for $30 \mathrm{~min}$ before exposure to FDA and these embryos did not accumulate fluorescein.

Fig. 5. A u.v. light photograph showing a freshly collected 2-cell mouse embryo in a solution of fluorescein in PB1. The embryo excludes fluorescein and hence appears dark.

Fig. 6. A u.v. light photograph showing a 2-cell mouse embryo in a solution of fluorescein as in Fig. 5. The embryo has been heated at $56^{\circ} \mathrm{C}$ for $30 \mathrm{~min}$ and retained the ability to exclude fluorescein. Both blastomeres had expanded within the zona pellucida giving a spherical appearance.

Figs 7 and 8. Three freshly collected mouse embryos exposed to FDA and photographed as for Figs 1 and 2. One of the embryos had suffered membrane damage and did not fluoresce under u.v. light.

\section{PLATE 2}

Figs 9 and 10. Four freshly collected 1-cell mouse embryos exposed to FDA and photographed as for Figs 1 and 2 . The membranes of 2 embryos were mechanically punctured after exposure to FDA, leading to loss of intracellular fluorescein.

Figs 11 and 12. Two morula-stage mouse embryos after exposure to FDA and photographed as for Figs 1 and 2. The morula on the right was cultured for $24 \mathrm{~h}$ under paraffin oil, the one on the left was cultured for $24 \mathrm{~h}$ without oil. The morula cultured under oil was unable to accumulate fluorescein.

Figs 13 and 14. A blastocyst exposed to FDA and photographed as for Figs 1 and 2. This blastocyst developed from a morula cultured for $48 \mathrm{~h}$ without paraffin oil.

Figs 15 and 16. Three mouse embryos exposed to FDA and photographed as for Figs 1 and 2. All 3 embryos had been in culture for $48 \mathrm{~h}$ with the embryo on the right cultured under oil (no fluorescence) while the remaining embryos were cultured without oil. 
PLATE 1

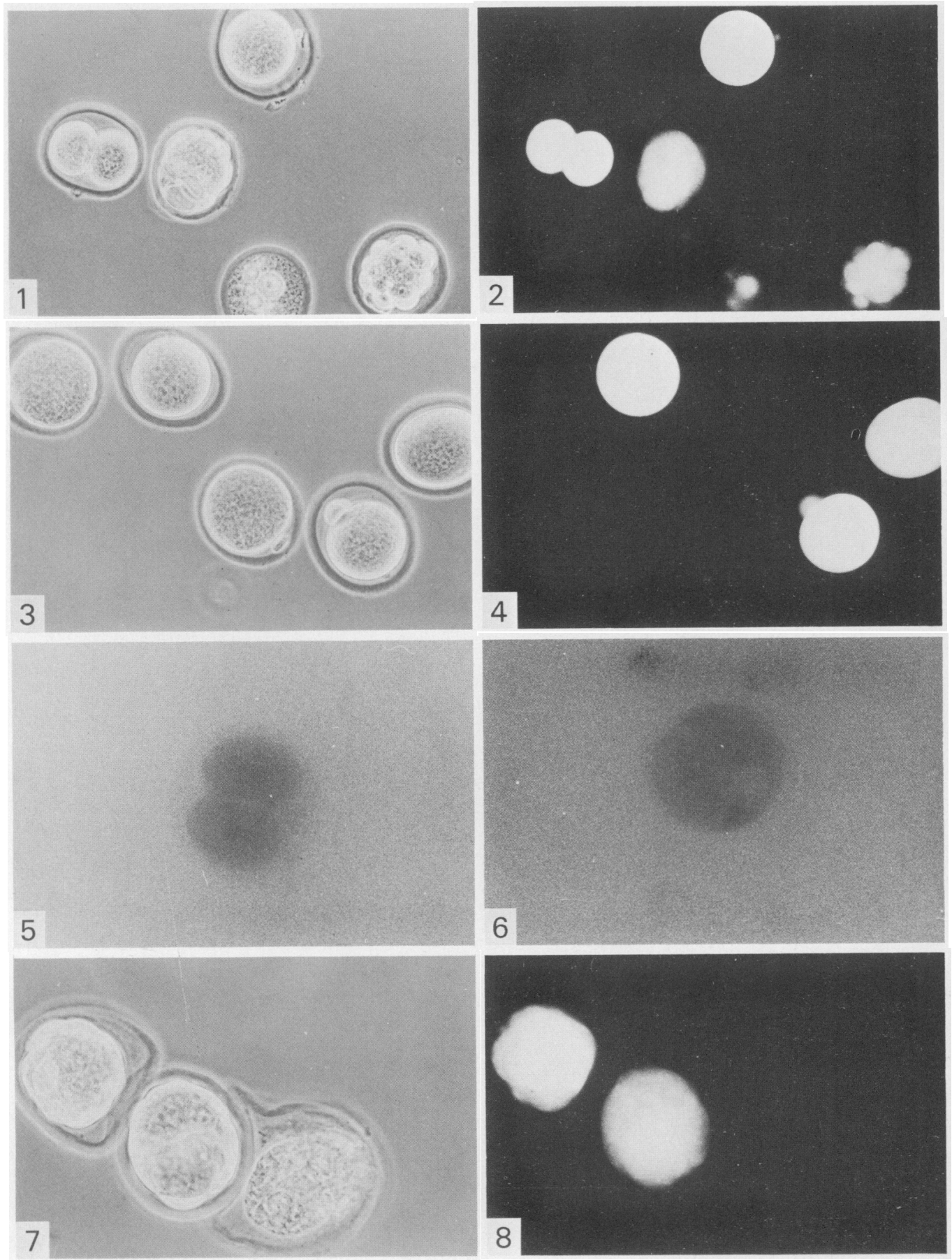

(Facing p. 192) 
PLATE 2

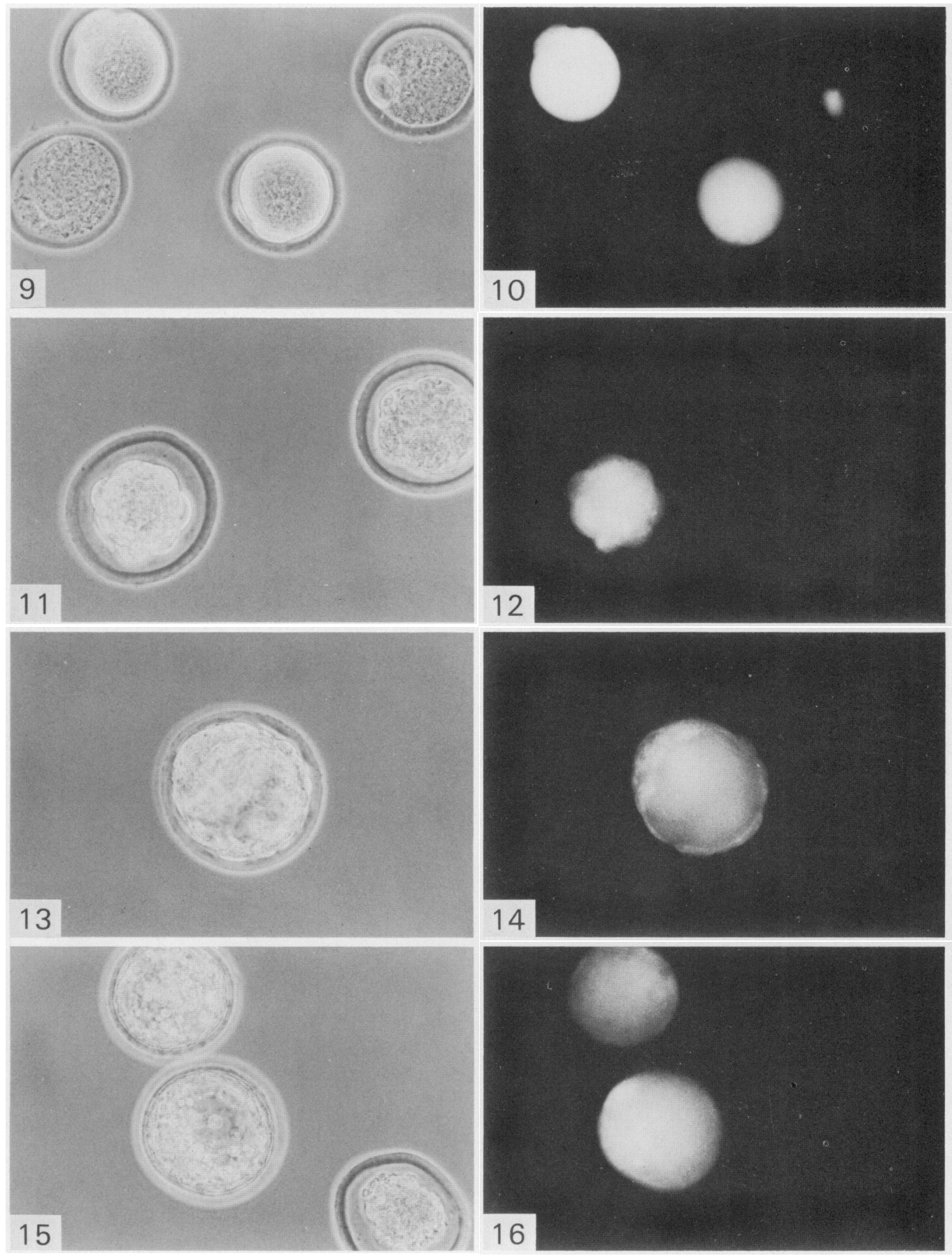




\section{PLATE 3}
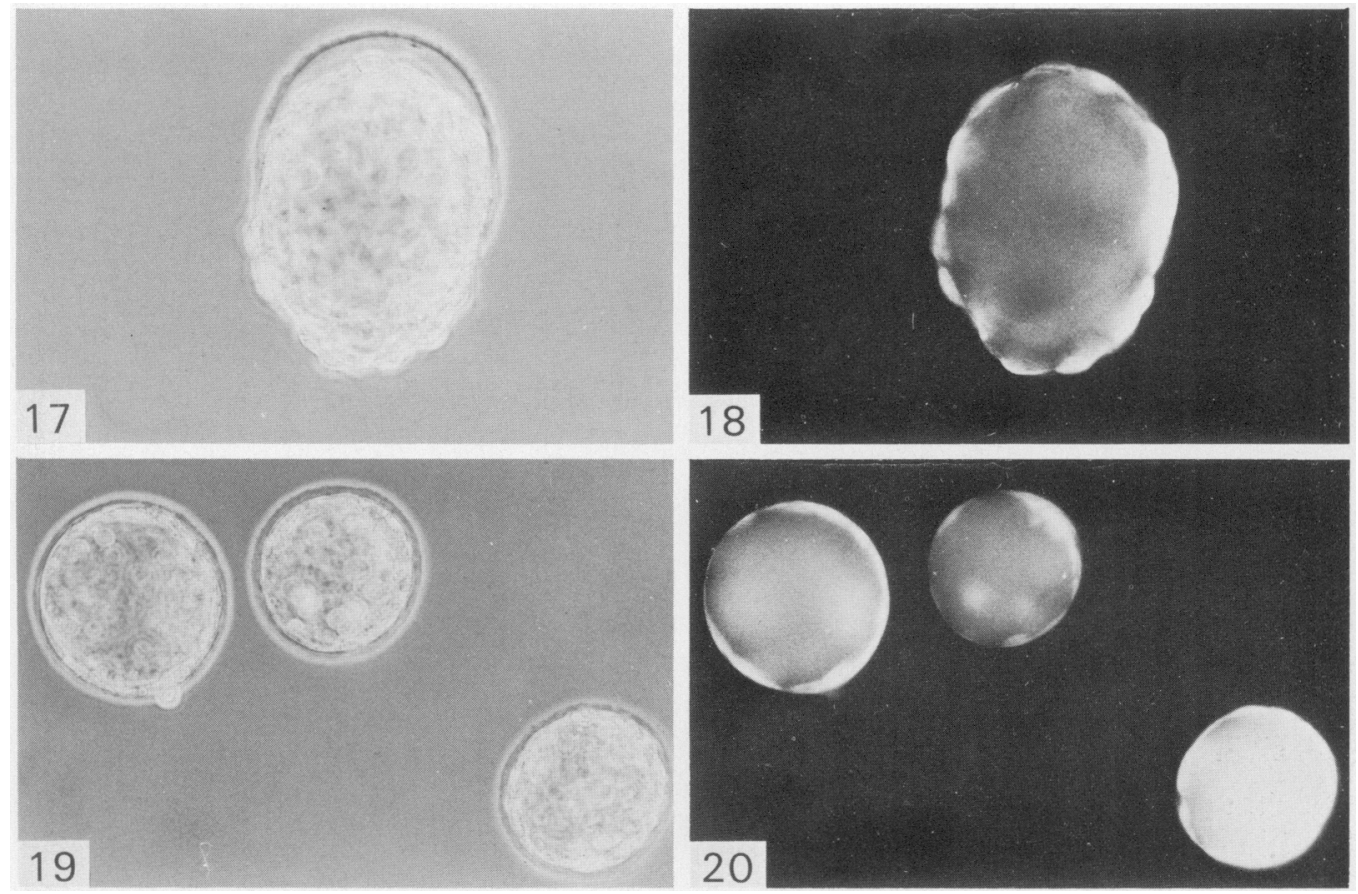

Figs 17 and 18. A hatching blastocyst found $72 \mathrm{~h}$ after a 2 -cell embryo exposed to FDA was placed in culture. The blastocyst was re-exposed to FDA and photographed as for Figs 1 and 2 . Note the localization of fluorescein in the cells of the blastocyst.

Figs 19 and 20. Three blastocysts found $72 \mathrm{~h}$ after 2 -cell embryos not exposed to FDA were placed in culture. The blastocysts were exposed to FDA and photographed as for Figs 1 and 2. 


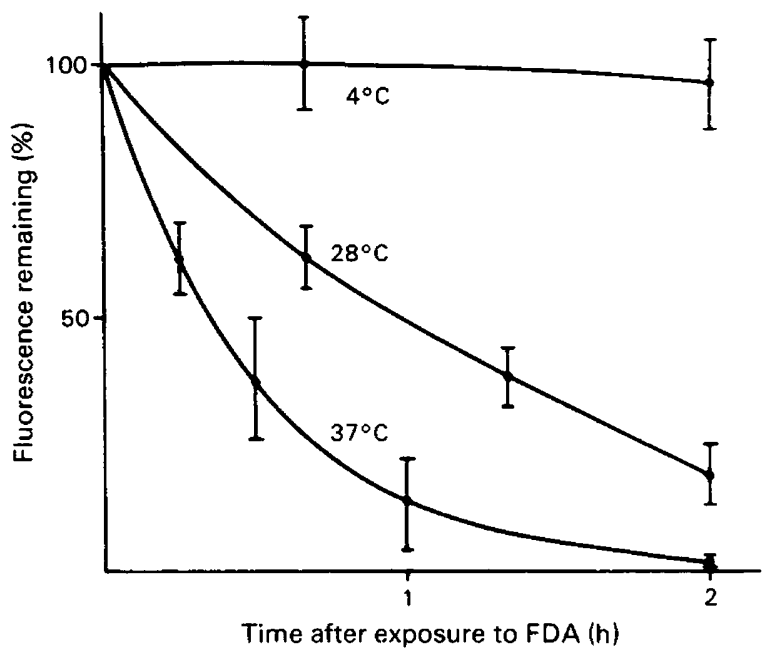

Text-fig. 1. Loss of accumulated fluorescein (mean \pm s.e.m.) from 1-cell mouse embryos stored at 37,28 and $4^{\circ} \mathrm{C}$.

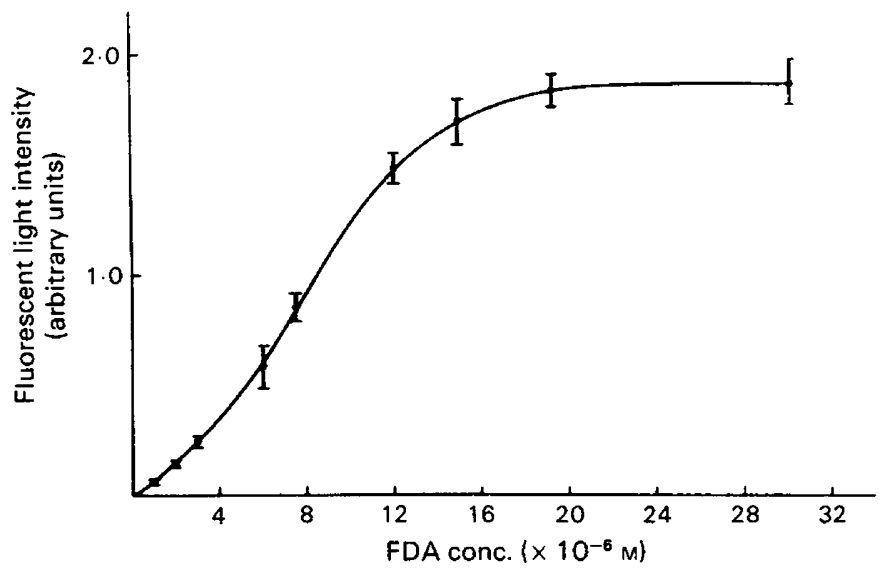

Text-fig. 2. Fluorescent light intensity (mean \pm s.e.m.) of 1-cell mouse embryos exposed for 1 min to different concentrations of FDA.

The rate at which intracellular fluorescein was accumulated was dependent on the concentration on FDA (Text-fig. 2). The rate of fluorescein accumulation increased rapidly at concentrations of FDA from $2 \times 10^{-6} \mathrm{M}$ to $14 \times 10^{-6} \mathrm{M}$. At concentrations above $18 \times 10^{-6} \mathrm{M}$ there was little increase in the rate of fluorescein accumulation. The $K_{\mathrm{m}}$ (concentration of substrate giving half the maximal rate) of 1-cell mouse embryos was $8.5 \times 10^{-6} \mathrm{M}$. The concentration of FDA used in our experiments was $6 \times 10^{-6} \mathrm{M}$.

\section{Effect of in-vitro culture on fluorescence}

Morulae were flushed from mouse uteri and randomly divided into two groups. The 42 morulae in one group were placed in culture tubes prepared as described in 'Materials and Methods'. The 46 morulae in the other group were placed in tubes containing medium to which paraffin oil (specific gravity $1 \cdot 2-1 \cdot 1$ ) had been added $12 \mathrm{~h}$ previously. The paraffin oil was known to provide less than adequate culture conditions because in preliminary experiments all embryos placed under oil had failed to continue development. Within $24 \mathrm{~h}$ under oil, all 46 
morulae had lost the ability to accumulate fiuorescein when exposed to FDA and displayed fluorescence at Grade 0 (Pl. 2, Figs 11 and 12). The 42 embryos cultured without oil retained the ability to accumulate intracellular fluorescein when exposed to FDA after $48 \mathrm{~h}$ in culture, by which time 25 of these embryos had formed blastocoele cavities (Pl. 2, Figs 13 and 14). After 48 $\mathrm{h}$ in culture, all embryos under oil had degenerated and no blastocysts were formed (Pl. 2, Figs 15 and 16).

\section{Effect of FDA on continued development in vitro}

Exposure of freshly collected 2-cell embryos to FDA for $1 \mathrm{~min}$ and u.v. light for $10 \mathrm{sec}$ did not alter the ability of the embryos to continue development in vitro. Blastocyst formation was not significantly different from that of the control group: 50 (79\%) blastocysts were found $72 \mathrm{~h}$ after 63 2-cell embryos had been exposed to FDA and u.v. light, while 48 (75\%) blastocysts developed from 64 untreated control embryos $\left(\chi_{1}^{2}=0.05\right.$; N.S.). Some of the blastocysts treated were hatched and expanded and when blastocysts were re-exposed to FDA the cells fluoresced brightly (Pl. 3, Figs 17, 18, 19 and 20).

\section{Effect of FDA on continued development in vivo}

Exposure of freshly collected blastocysts to FDA and u.v. light did not alter their ability to implant and develop normally in vivo. Treated embryos were transferred to 14 recipients and 7 of these became pregnant; 7 out of 13 control recipients were pregnant. Embryo survival within the pregnant mice did not differ significantly: 34 (45\%) normal fetuses were found 14 days after transfer of 75 treated embryos and $42(49 \%)$ normal fetuses were found 14 days after transfer of 85 control embryos $\left(\chi_{1}^{2}=0 \cdot 13 ;\right.$ N.S. $)$.

Examination under the dissecting microscope showed that all treated fetuses appeared at the same stage of development as the controls and were indistinguishable from them. No abnormal fetuses were found.

\section{Discussion}

The ability to hydrolyse fluorescein diacetate and produce intracellular fluorescein was displayed consistently by all stages of freshly collected mouse embryos. The rate at which fluorescein is accumulated in individual embryos varies greatly even between embryos at the same stage of development. A large cell-to-cell variation in fluorescence has been reported for other mammalian cells (Rotman \& Papermaster, 1966). The factor most likely to account for some of the variability in fluorescence between cells is the time of exposure to FDA. The intensity of fluorescence increased with time up to $20 \mathrm{~min}$ when bone marrow cells were exposed to FDA (Persidsky \& Baillie, 1977). To overcome this, embryos to be compared were exposed to FDA and washed together where possible. Great care was also taken to be consistent with defining the start and finish of the incubation time. All incubations and washes were carried out at room temperature which varied between 24 and $28^{\circ} \mathrm{C}$. It is unlikely that this temperature variation had a significant effect on the rate of fluorescein accumulation because fluorescence intensity, for a constant exposure time to FDA, does not increase with temperatures between 22 and $40^{\circ} \mathrm{C}$ (Persidsky \& Baillie, 1977).

The concentration of FDA used in these experiments, $6 \times 10^{-6} \mathrm{M}$, was chosen in order to achieve a short incubation time associated with an accumulation of a readily detectable amount of fluorescein. At this concentration of FDA, substrate is limiting (see Text-fig. 2) but this concentration was already 5 times that used by Rotman \& Papermaster (1966). As solutions con- 
taining more than $1 \mu \mathrm{g} \mathrm{FDA} / \mathrm{ml}$ tend to flocculate (Rotman \& Papermaster, 1966) and the solution we prepared $(2.5 \mu \mathrm{g} / \mathrm{ml})$ did flocculate when standing, it was not considered advantageous to use a concentration of FDA for which substrate was not limiting as such a solution would have to have contained $7.5 \mu \mathrm{gDA} / \mathrm{ml}$. The $K_{\mathrm{m}}$ value for 1-cell embryos which we found $\left(8.5 \times 10^{-6} \mathrm{M}\right)$ is of the same order of magnitude as the $K_{\mathrm{m}}$ value reported for intact mouse lymphoma cells $\left(2.9 \times 10^{-6} \mathrm{M}\right.$; Rotman \& Papermaster, 1966),

The rate at which intracellular fluorescein is lost from 1-cell mouse embryos decreases as the temperature at which they are stored decreases. Similar results have been reported for bone marrow cells exposed to FDA and stored at 5, 20 and $37^{\circ} \mathrm{C}$ (Persidsky \& Baillie, 1977). The almost complete loss of intracellular fluorescein after $2 \mathrm{~h}$ at $37^{\circ} \mathrm{C}$ means that embryos may be assessed repeatedly at relatively short intervals of time during culture. The FDA test may be able to detect inadequacies in culture conditions before they are evident morphologically.

Exposure to FDA has no effect on the subsequent cloning efficiency of mouse lymphoma cells (Rotman \& Papermaster, 1966) and we also found no effect on blastocyst formation when mouse embryos were exposed to FDA at the 2-cell stage. The blastocysts formed by $96 \mathrm{~h}$ after ovulation, from the culture of 2-cell embryos exposed to FDA, were hatching and expanded and this corresponds closely with the development times in vivo and in vitro reported by Smith \& McLaren (1977). The blastocoele cavity of embryos cultured in vitro did not fluoresce as brightly as the surrounding cells after exposure to FDA. While the elemental composition of blastocoele fluid has been analysed (Borland, Biggers \& Lechene, 1977), little is known of its protein composition or enzyme activity. Blastocoele fluid is thought to be formed by secretion by cells of the blastocyst (Tarkowski \& Wroblewska, 1967) and by uptake of material from the surrounding medium (Beier \& Maurer, 1975). As FDA can readily move through cells, the lack of fluorescence may indicate the absence of esterase enzyme activity in blastocoele fluid of blastocysts cultured in vitro.

In the present experiments exposure of preimplantation embryos to FDA and u.v. light had no apparent effect on implantation rates or post-implantation development. Intracellular fluorescein is unlikely to exert any adverse consequences in the long term as fluorescein passed out of the cells within a few hours at $37^{\circ} \mathrm{C}$. Similarly, exposure to u.v. light of $450-490 \mathrm{~nm}$ for $10 \mathrm{sec}$ is unlikely to cause DNA lesions as DNA absorption is insignificant at wavelengths greater than $320 \mathrm{~nm}$ (Stryer, 1975).

While we have demonstrated that loss of esterase enzyme activity preceded loss of embryo viability, assessed by morphological appearance, it cannot be concluded that esterase enzyme activity is essential for 'cell life'. About 100 enzymes are believed to be necessary for cell life, and while esterase enzymes are included in the list, the Norikoff hepatoma, usually fatal within days, does not possess any esterase enzyme activity (Dolan, 1965). It can be concluded, however, that the simple, rapid, non-toxic procedure described in the present paper to test esterase enzyme activity and membrane integrity may be very useful for assessing the viability of preimplantation embryos.

\section{References}

Anderson, G.B. \& Foote, R.H. (1974) Effects of low temperature storage upon subsequent energy metabolism of rabbit embryos. Expl Cell Res. 87, 302306.

Anderson, G.B. \& Foote, R.H. (1975) Effects of low temperature upon subsequent nucleic acid and protein synthesis of rabbit embryos. Expl Cell Res. 90, 73-78.

Beier, H.M. \& Maurer, R.R. (1975) Uteroglobin and other proteins in rabbit blastocyst fluid after development in vivo and in vitro. Cell Tiss. Res. 159, 1-10.
Borland, R.M., Biggers, J.D. \& Lechene, C.P. (1977) Studies on the composition and formation of mouse blastocoele fluid using electron probe microanalysis. Devl Biol. 55, 1-8.

Dolan, M.F. (1965) Viability assays - a critique. Fedn Proc. Fedn Am. Socs exp. Biol., Suppl. 15, S275S279.

Hoppe, P.C. \& Pitts, S. (1973) Fertilization in vitro and development of mouse ova. Biol. Reprod. 8, 420426.

Jackowski, S.C. (1977) Physiological differences be- 
tween fertilized and unfertilized mouse ova; glycerol permeability and freezing sensitivity. Ph.D dissertation, University of Tennessee, Knoxville.

Leibo, S.P. \& Mazur, P. (1978) Methods for the preservation of mammalian embryos by freezing. In Methods in Mammalian Reproduction, pp. 179-201. Ed. J. C. Daniel. Academic Press, New York.

McGrath, J.J., Cravalho, E.G. \& Huggins, C.E. (1975) An experimental comparison of intracellular ice formation and freeze-thaw survival of hela S-3 cells. Cryobiology 12, 540-550.

Persidsky, M.D. \& Baillie, G.S. (1977) Fluorometric test of cell membrane integrity. Cryobiology 14, 322-331.

Rotman, B. \& Papermaster, B.W. (1966) Membrane properties of living mammalian cells as studied by enzymatic hydrolysis of fluorogenic esters. Proc. natn. Acad. Sci. U.S.A. 55, 134-141.
Smith, R. \& McLaren, A. (1977) Factors affecting the time of formation of the mouse blastocoele. $J$. Embryol. exp. Morph. 41, 79-92.

Stryer, L. (1975) Biochemistry. W. H. Freeman and Company, San Francisco.

Tarkowski, A.K. \& Wroblewska, J. (1967) Development of blastomeres of mouse eggs isolated at the 4 and 8 cell stage. J. Embryol. exp. Morph. 18, 155180.

Whitten, W.K. \& Champlin, A.K. (1978) Pheromones, estrus, ovulation and mating. In Methods in Mammalian Reproduction, pp. 403-416. Ed. J. C. Daniel. Academic Press, New York.

Whittingham, D.G. (1971) Survival of mouse embryos after freezing and thawing. Nature, Lond. 233, 125126.

Whittingham, D.G. (1978) Viability assays for mammalian ova. Cryobiology 15, 245-248.

Received 4 May 1979 